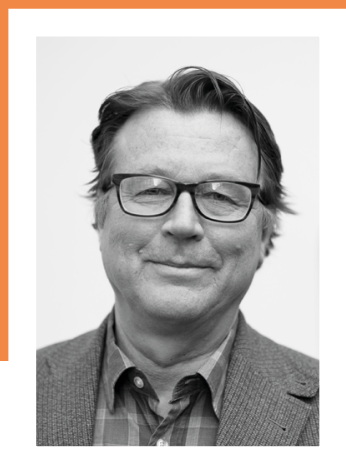

\title{
PÄ̈̈KIRJOITUS
}

\section{VAIN RIIPPUMATON ARVIOINTI ON USKOTTAVAA}

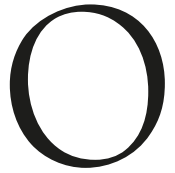

PetUshallitus (OPH) SAI 1990luvulla tehtäväkseen huolehtia koulutuksen arvioinnista. Arviointi sai lakisääteisen aseman vuoden 1998 koulutuksen lainsäädännössä, ja OPH:sta tuli ulkopuolisten arviointien toimeenpanija.

Jo tuolloin eduskunnan sivistysvaliokunta ilmaisi huolensa viraston kaksoisroolista: Yhtältä OPH päätti koulutuksen järjestämisestä ja hyväksyi opetussuunnitelman perusteet. Toisaalta se vastasi koulutuksen ulkopuolista arvioinnista ja arvioinnin kehittämisestä.

2000-luvulle tultaessa kävi selväksi, että opetushallintoon sijoitettu ulkopuolinen arviointi ei ollut uskottavalla tavalla riippumatonta. Eikä se täyttänyt ulkopuolisen arvioinnin tunnusmerkkejäkään, kun arvioinnin tekijä sisältyi arvioitavaan kokonaisuuteen. Koulutuksen arvioinnista käytiin valtakamppailua. OPH joutui luovuttamaan ison osan arviointitoimintaa vuonna 2003 aloittaneelle Koulutuksen arviointineuvostolle.

ARVIOINNIN USKOTTAVUUS ja riippumattomuus paranivat, mutta samalla oltiin tilanteessa, jossa koulutuksen arviointikentällä toimi kolme erillistä organisaatiota, $\mathrm{OPH}$, Korkeakoulujen arviointineuvosto (KKA) ja Koulutuksen arviointineuvosto (KAN). Lisäksi lääninhallitukset arvioivat koulutuksen saavutettavuutta ja perusturvaa osana peruspalvelujen arviointia. Moninapainen järjestelmä hukkasi vähiä voimavaroja, eivätkä organisaatiot kyenneet keskinäiseen yhteistoimintaan, vaikka se olisi ollut monien tärkeiden arviointikohteiden kannalta välttämätöntä.

Erityisen tärkeää olisi ollut yhteistoiminta sekä OPH:n ja KAN:n ja toisaalta KKA:n ja KAN:n kesken. Uudenlainen mielekäs arviointi tuli mahdolliseksi, kun erilliset arviointiorganisaatiot lakkautettiin ja kaikki arviointitoiminta siirrettiin uuteen Kansalliseen koulutuksen arviointikeskukseen (KARVI) vuonna 2014. Koko koulutuksen kenttää nivelvaiheineen ja oppilasvirtoineen päästiin tarkastelemaan ja arvioimaan ensimmäistä kertaa yhtenäisenä hankkeena. KARVI alkoi nopeasti tuottaa laadukkaita ja yhteiskunnallisesti merkittäviä arviointeja.

MATKA YHDEKSI KESKUKSEKSI kOottuun arviointitoimintaan oli ollut toraisa ja mutkikas. Juuri kun KARVI oli aloittanut toimintansa, keskushallinnon virastoselvityshankkeessa ehdotettiin, että 
se liitettäisiin takaisin OPH:een. Ylioppilastutkintolautakunnan ja KARVIN liittämistä valmistellut työryhmä sai esityksensä valmiiksi tämän vuoden tammikuussa. Sekä Ylioppilastutkintolautakunta että KARVI vastustavat työryhmän esitystä ja jättivät esitykseen eriävän mielipiteensä.

Työryhmä ei perustele liittämistä arvioinnin lähtökohdista käsin eikä edes taloudellisilla säästöillä. Syynä ei siten ole esimerkiksi koulutuksen arvioinnissa havaittujen puutteiden korjaaminen, arvioinnin kehittäminen tai sen edellytysten parantaminen muutoin. Työryhmän esityksestä käy selvästi ilmi siirron uhka arvioinnin riippumattomuudelle, mutta sitä ei pidetä nykyjärjestelmän romuttamisen esteenä.

KARVI esittää eriävässä mielipiteessään huolensa arviointitoiminnan uskottavuuden säilymisestä niin Suomessa kuin kansainvälisesti. Uskottavuuden kannalta ensiarvoisen tärkeä arvioinnin riippumattomuus ja itsenäinen päätöksenteko ovat siirrossa uhattuna. KARVI ennakoi uuden aseman OPH:n yhteydessä vaarantavan arviointitoiminnan resurssit ja rapauttavan riittävän laaja-alaisen ja kattavan arvioinnin. KARVIn hallinto- ja tukipalveluiden kustannukset uhkaavat kasvaa huomattavasti nykyisestä tasosta.

Toteutuessaan esitys veisi koulutuksen arvioinnin hallinnon ulkopuolelta takaisin hallinnon sisälle, mikä on riippumattomuuden ja uskottavuuden kannalta ongelmallinen tilanne. Miten uskottavaa on, että KARVI onnistuu säilyttämään riippumattomuuden arvioidessaan koko koulutusjärjestelmän toimivuutta, mihin sisältyvät myös $\mathrm{OPH}$ :n vastuulla olevat toiminnot? OPH arviointitoiminnan riippumattomuuden takaajana on kuin pukki kaalimaan vartijana.

KARVIn nykyinen asema riippumattomana ja luotettavana arviointitoimijana täyttää kansainväliset kriteerit korkeakoulujen laatujärjestelmien pätevänä auditoijana. Nyt kuitenkin siirto opetushallinnon sisälle uhkaa johtaa KARVIn poistamiseen virallisesti hyväksyttyjen korkeakoulutuksen auditoijien eurooppalaisesta rekisteristä. Riippumattomuuden vaatimus on kansainvälisissä arvioinneissa ehdoton.

KOULUTUKSEN ARVIOINTIA on hyvä tarkastella myös demokratian näkökulmasta. Arviointi tuottaa tietoa, jonka avulla kansalaiset veronmaksajina ja koulutuspalvelujen käyttäjinä saavat vakuutuksen, että koulutus järjestetään asianmukaisella tavalla läpinäkyvyyden ja laadunvarmistuksen periaatteita noudattaen ja että järjestelmä tuottaa hyviä oppimistuloksia tasa-arvoisesti. Ollakseen kansalaisten silmissä luotettavaa ja uskottavaa arvioinnin täytyy olla riippumatonta ja selvästi opetushallinnon ulkopuolella.

Kun arviointitoiminta asemoidaan OPH:n pääjohtajan peukalon alle, siltä viedään riippumattomuus. Tekeillä oleva muutos saattaa koko arvioinnin uskottavuuden kyseenalaiseksi. Vakuuttelut eivät uskoa riippumattomuuteen palauta.

HEIKKI SILVENNOINEN 